\title{
PERSONAL BRANDING RACHEL GODDARD SEBAGAI BEAUTY TRAVEL DAN PARODY VLOGGER
}

\author{
Natasha Putri Tumakaka ${ }^{1}$, Susanne Dida ${ }^{2}$ dan FX Ari Agung Prastowo ${ }^{3}$ \\ ${ }^{1}$ United Tractors \\ ${ }^{2,3}$ Universitas Padjadjaran \\ Email : nptumakaka@gmail.com
}

\begin{abstract}
ABSTRAK
Rachel Goddard memilih youtube untuk menjadi media utama dalam mata pencahariaanya. Melalui kegiatan video blogging, Rachel membuat konten-konten yang mendukung passionnya dalam berkarya. Sebagai sosok yang menggunakan dirinya sebagai pusat dari pekerjaannya, sangatlah perlu untuk memasarkan dirinya secara sistematis, secara singkat dapat dibilang bahwa seorang Youtuber perlu melakukan personal branding terhadap dirinya. Rachel mem-branding dirinya sebagai Beauty, Travel and Parody Vlogger yang ditunjukkan melalui akun Youtubenya. Rachel Goddard telah mengetahui identitas yang ingin dikeluarkan dalam dirinya kepada orang lain juga tujuan yang ia miliki dalam membuat video blog, Rachel memiliki cara untuk membentuk identitas onlinenya dalam proses personal brandnya sebagai beauty, travel \& parody vlogger melalui video-video yang ia buat dan Rachel Goddard membentuk identitas online yang ia miliki dan apa yang menjadikannya menarik namun Rachel belum bisa menunjukkan konsistensi dirinya secara maksimal dalam pemerataan konten, penggunaan identitas online.
\end{abstract}

Kata kunci: personal branding, Youtuber, Identitas, Online, Video Blog

\section{PENDAHULUAN}

Personal Branding adalah
sebuah proses ketika orang
menggunakan dirinya atau karirnya sebagai merek (brand) dan bagaimana kita memasarkan diri kita pada orang lain secara sistematis. Hal yang ditonjolkan tersebut sering kali merupakan ciri khas dari pribadi orang tersebut sehingga masyarakat dapat memiliki pengertian spesifik ketika melihat karya mereka. Personal branding dapat dilakukan oleh siapapun, dan tidak terkecuali profesi apapun. Salah satu profesi yang sedang naik daun di tahun 2018 ini adalah Youtuber. Menjadi seorang Youtuber yang menggunakan dirinya sebagai pusat dari pekerjaannya, sangatlah perlu untuk memasarkan dirinya secara sistematis, secara singkat dapat dibilang bahwa seorang Youtuber perlu melakukan personal branding terhadap dirinya. Dalam dunia per-Youtube-an Indonesia, salah satu konten Youtube yang 
menarik banyak minat adalah konten how to atau tutorial make-up.

Salah satu Youtuber yang memiliki konten dibidang beauty yang tengah digandrungi oleh para remaja perempuan hingga wanita dewasa di Indonesia adalah Rachel Goddard. Yang membedakan Rachel Goddard dengan Beauty Vlogger lainnya adalah konten Vlognya yang mengkombinasikan beauty, travel dengan parody yang tentunya menjadi sebuah keunikan sendiri. Dalam menyampaikan kontennya, Rachel Goddard selalu memiliki caranya sendiri dalam berkomunikasi yang menjadi ciri khas dalam setiap vlog-nya.

Dalam vlognya, Rachel memiliki konten yang beragam mengenai make-up, traveling, dan juga parodi yang dikemas dalam waktu lebih kurang 10 menit. Berdasarkan hasil wawancara, Rachel ingin berkomunikasi dengan para viewers-nya dan menganggap mereka sebagai teman pribadinya dan tidak jaim dalam menyampaikan pesan tersebut. Berbeda dengan beauty vlogger pada umumnya, Rachel punya gaya dan ciri khas tersendiri yang membuat para fans-nya begitu menantikan video baru dari wanita cantik tersebut. Rachel dikenal menampilkan ekspresi wajah yang kocak di video tutorial karyanya. Nggak cuma soal makeup, ada beberapa video lain yang dipersembahkan Rachel untuk penonton. Mulai dari challengechallenge seru hingga travel vlog yang membuat kita bisa lebih mengenal sosok Rachel lebih dekat. Serunya lagi, semua tema tersebut dibungkus dengan nuansa fun dan lucu. Dalam videonya dapat terlihat bahwa Rachel tidak sungkan untuk membuat mimik yang lucu dan tidak biasa untuk mempertegas sifatnya yang tidak malu-malu dalam vlognya. Rachel dengan percaya diri menunjukkan mimik-mimik yang unik ketika melakukan salah satu ciri khusus dari vlognya yaitu template ketika meminta para viewers untuk memberikan like pada video tersebut. Namun terlepas dari template tersebut, memang Rachel memiliki ekspresi yang tidak biasa yang sengaja ia tunjukkan dalam setiap videonya. Oleh karena itu, peneliti tertarik untuk menjadikan Rachel 
Goddard sebagai subjek penelitian ini.

Dengan segala keunikan yang dimilikinya, Rachel Goddard kini telah menjadi vlogger ternama di Indonesia dengan total subscribers sebanyak 1.085.257 subscribers, dengan jumlah total video sebanyak 319 video dan video views sebanyak 112.267.584 kali. Kesuksesan Rachel Goddard dibuktikan dengan berbagai kerjasama yang telah dilakukannya dengan bermacam-macam brand, mulai dari brand kecantikan seperti make up dan skin care, brand pakaian hingga perusahaan e-commerce. Selama Rachel berkecimpung dalam dunia Youtube, Rachel sudah pernah masuk dalam nominasi dari beberapa acara awards bahkan memenangkannya seperti pada BeautyFest Asia 2018, Rachel memenangkan nominasi Beauty Creator of The Year. Rachel membranding dirinya sebagai Beauty, Travel and Parody Vlogger yang ditunjukkan melalui channel art.

\section{Dalam pembentukkan} personal branding terdapat beberapa tahapan yang sebaiknya dilakukan untuk memaksimalkan penyampaian dari personal branding tersebut. Tahapan tersebut terbagi menjadi 3 tahapan yaitu, extract, express dan exude. Tiap tahapan tersebut membantu proses personal branding yang dilakukan akan menjadi maksimal karena membantu untuk mengetahui apa keunikan yang dimiliki, identitas online yang akan ditunjukkan dan mengetahui konsistensi dalam kegiatan personal branding yang dilakukan. Berdasarkan fenomena diatas, peneliti tergugah untuk melakukan penelitian terhadap personal branding Rachel Goddard sebagai beauty, travel and parody vlogger yang belum sepenuhnya berhasil.

Personal Branding adalah suatu proses ketika orang menggunakan dirinya atau karirnya sebagai merek (brand). Personal Branding adalah bagaimana kita memasarkan diri kita pada orang lain secara sistematis (Ganiem dalam Wasesa, 2011:282). Personal branding merupakan seni untuk menarik dan menjaga persepsi publik secara aktif. Personal branding dapat dibangun dari orang, nama, tanda, simbol, atau desain yang dapat dijadikan pembeda dengan 
kompetitor. Orang yang mengelola personal branding dengan baik, cenderung mendapat popularitas sesuai atau mendekati harapannya. Upaya tersebut dapat dilakukan dengan berbagai cara layaknya strategi pemasaran (Ganiem dalam Wasesa, 2011:282)

Personal brand juga diartikan sebagai suatu kesan yang berkaitan dengan nilai, keahlian, perilaku maupun prestasi yang dibangun oleh seseorang baik secara sengaja ataupun tidak sengaja dengan tujuan untuk menampilkan citra dirinya. (Parengkuan \& Tumewu, 2014:18).

Personal brand dapat dibedakan menjadi dua, yakni natural personal brand dan created personal brand. Natural personal brand (Parengkuan \& Tumewu, 2014:17) merupakan personal brand yang terbentuk secara tidak sengaja. Hal ini dapat terjadi ketika seseorang sudah memiliki nilai dan prinsip yang kuat dalam dirinya dan menerpakannya dalam kehidupan sehari-hari, sehingga saat ia dihadapkan pada berbagai situasi khususnya dalam menjalani karir, ia sudah mengetahui dan memahami apa yang dibutuhkan, diinginkan serta disukai.

Created personal brand (Parengkuan \& Tumewu, 2014:17) merupakan personal brand yang dibentuk dengan sengaja sesuai dengan apa yang diinginkan. Seseorang dapat membentuk personal brand sesuai dengan keinginannya melalui berbagai upaya yang dilakukan secara berkelanjutan. Created personal brand dapat bertahan jika berdasarkan pada komponen-komponen personal brand yang peneliti jelaskan sebelumnya.

Pada dasarnya, personal branding merupakan kegiatan public relations dengan pembedanya adalah dalam public relations, yang dipresentasikan adalah citra daripada sebuah organisasi atau perusahaan. Pada personal branding, yang dipresentasikan adalah citra diri seorang tersebut. Sama seperti personal branding, public relations menurut Frank Jeffkins (2003:7) adalah sesuatu yang terdiri dari semua bentuk komunikasi berencana, baik ke dalam maupun ke luar dengan tujuan untuk mendapatkan citra positif dan dukungan dari publiknya. 
Rachel Goddard menggunakan dirinya atau karirnya sebagai merek (brand). Rachel sebagai seorang vlogger mencoba memasarkan dan mengkomunikasikan apa yang ada pada dirinya kepada orang lain.

\section{Konsep personal branding} pertama kali dikenalkan pada tahun 1997 oleh Tom Peters dalam artikelnya dalam majalah Fast Company yang berjudul The Brand Called You (Arruda \& Dixson, 2007:24). Ia memandang personal branding dengan mengatakan bahwa kita adalah CEO dari diri kita sendiri. Pekerjaan terpenting kita adalah menjadi pemasar dari brand atau merek kita (Peters, 1997). Dari pernyataan tersebut dapat dijelaskan bahwa personal branding erat kaitannya dengan cara seseorang membangun diri, mempromosikan diri serta memasarkannya ke orang lain.

Sejak saat itu, banyak ahli lain yang berpendapat mengenai definisi personal branding. Personal branding adalah cara yang paling efektif untuk mengklarifikasi apa yang membuat seseorang berbeda, khusus, dalam pandangan orang lain yang mana kualitas tersebut dapat membimbing karir kedepannya. Personal branding tidak lain tentang menggali atribut yang seseorang miliki seperti kekuatan, keterampilan dan kegemaran atau hasrat yang digunakan untuk menonjol dari orang lain. (Arruda \& Dixson, 2007:29).

\section{METODE PENELITIAN}

Penelitian ini menggunakan metode deskriptif. Penelitian deskriptif adalah pencarian fakta dengan interpretasi yang tepat. Penelitian deskriptif mempelajari masalah-masalah dalam masyarakat serta tata cara yang berlaku dalam masyarakat serta situasi-situasi tertentu, termasuk tentang hubungan, kegiatan-kegiatan, sikap-sikap, pandangan-pandangan, serta prosesproses yang sedang berlangsung dan pengaruh-pengaruh dari suatu hubungan fenomena (Whitney dalam Nazir, 2009:54-55).

Metode deskriptif juga dapat diartikan sebagai suatu metode dalam meneliti status sekelompok manusia, suatu objek, suatu set kondisi, suatu sistem pemikiran, ataupun suatu kelas peristiwa pada masa sekarang. Tujuan dari penelitian deskriptif ini adalah 
untuk membuat deskripsi, gambaran atau lukisan secara sistematis, faktual dan akurat mengenai fakta-fakta, sifat-sifat serta hubungan antar fenomena yang diselidiki (Nazir, 2009:54).

Penelitian deskriptif adalah
suatu bentuk penelitian yang ditujukan untuk mendeskripsikan fenomena-fenomena yang ada, baik fenomena alamiah maupun fenomena buatan manusia. Fenomena ini bisa berupa bentuk, aktivitas, karakteristik, perubahan, hubungan, kesamaan, dan perbedaan antara fenomena satu dengan lainnya (Sukmadinata, 2006:72).

\section{Penelitian deskriptif berusaha}

untuk mendeskripsikan sesuatu misalnya kondisi atau hubungan, pendapat yang berkembang, proses yang sedang berlangsung, suatu efek yang terjadi, atau tentang kecenderungan akan sesuatu. Selain pengumpulan dan penyusunan data, dalam pelaksanaannya metode ini juga meliputi analisa dan interpretasi tentang arti data tersebut (Surakhmad, 1982:139).

Berdasarkan beberapa definisi di atas, penelitian ini menggunakan metode deskriptif karena bertujuan untuk menggambarkan atau mendeskripsikan fenomena dalam bentuk aktivitas atau proses yang sedang berlangsung. Aktivitas atau proses yang ingin dideskripsikan dalam penelitian ini adalah personal branding Rachel Goddard sebagai beauty travel \& parody vlogger. Sifat data dalam penelitian ini merupakan data kualitatif. Data kualitatif diungkapkan dalam bentuk kalimat serta urai-uraian, bahkan dapat berupa cerita pendek (bungin, 2007:103).

\section{HASIL DAN PEMBAHASAN}

William Arruda berpendapat bahwa personal branding adalah cara yang paling efektif untuk menjelaskan dan mengkomunikasikan apa yang membuat seorang individu berbeda, spesial, dan bernilai bagi orang lain yang dapat mengunakan kualitaskualitas tersebut untuk membangun karir. Melalui personal branding seseorang dapat dengan jelas menyampaikan janji dari nilai yang dimiliki untuk ditawarkan. William Arruda (2007: 29) mengatakan bahwa personal brand dapat menjadi reputasi yang dapat dibangun seiring berjalannya waktu dan menjadi sama 
atas bagaimana orang lain mendeskripsikan seseorang. Arruda meyakini bahwa kesuksesan individu dapat diraih melalui konsistensi personal brandnya yang dibangun melalui tiga tahap yaitu extract (mengeluarkan), express (mengekspresikan), exude (menunjukkan) (Arruda \& Dixson, 2007: 29).

Tahap Extract (Mengeluarkan) dalam Proses Personal Branding Rachel Goddard Sebagai Beauty Travel Parody Vlogger

Untuk melakukan personal branding, Rachel Goddard harus mengetahui jati dirinya. Siapa dirinya, apa identitasnya, apa tujuan utamanya atas kegiatan yang ia lakukan. Rachel juga harus mengetahui apa yang menjadi minat dan hasratnya, ketrampilan serta kemampuan yang ia miliki. Pada bagian ini, untuk mengetahui diri Rachel, wawancara dimulai dari pertanyaan mengenai apa identitas yang ingin dikeluarkan dari diri Rachel Goddard kepada khalayak.

Merujuk pada bukunya, William Arruda mengatakan bahwa personal brand adalah janji yang dimiliki seseorang. Maksud dari hal tersebut adalah apa yang seseorang tampilkan bagi orang lain berkesinambungan dengan apa yang orang-orang harapkan, dapat juga dimaknai sebagai bagaimana orangorang mengenalnya. Arruda (2007:35) menyatakan dalam bukunya bahwa setiap orang adalah pribadi yang unik, memiliki kombinasi dari keterampilan, kemampuan, dan kegemaran yang dapat mengisi tujuan hidup. Tahap ini adalah tahap dimana munculnya halhal dalam diri tersebut. Tujuan utama dari tahap extract ini adalah untuk mengeluarkan beberapa hal dalam diri individu seperti: identitas, tujuan, hasrat atau kegemaran, juga keterampilan (Arruda \& Dixson, 2007: 35).

Maka untuk bisa menampilkan personal branding dirinya, maka seseorang harus mengenal dirinya sendiri terlebih dahulu. Seseorang tersebut juga harus mengetahui bagaimana masyarakat menggambarkan dirinya. Sesuai yang dikemukakan William Arruda bahwa penting untuk mengetahui siapa diri seseorang untuk membuat dirinya 
berkembang (Arruda \& Dixson, 2007:

32). Arruda menjelaskan lebih lanjut mengenai pentingnya mengetahui diri sendiri bagi seseorang yang melakukan personal branding untuk membangun reputasi yang kokoh, seseorang harus memahami dan mengartikulasi apa yang dapat menjadi daya tarik dirinya bagi orang lain. Dibutuhkan suatu usaha yang keras dalam menentukan siapa diri seseorang. Bahkan bagi orang-orang yang memilki kesadaran diri dan introspektif, dalam menemukan siapa dirinya dibutuhkan upaya yang signifikan (Arruda \& Dixson, 2007: 35).

Leonita Julian seorang pengamat personal branding di Indonesia, juga mengatakan bahwa dalam melakukan personal branding, kita harus mengetahui bentuk kita seperti apa, kita itu siapa, tujuan yang kita punya, kelebihan, ciri khas, image dan juga mengetahui bagaimana orang melihat kita. Halhal tersebut yang membantu kita untuk mengetahui self-packaging yang seperti apa yang bisa kita lakukan. Karena personal branding tidak hanya mengenai bagaimana kita memasarkan diri, namun juga meliputi bagaimana kita mengemas diri kita atau bagaimana kita membentuk self-packaging kita dan juga bagaimana nantinya kita mengembangkan diri kita ke arah yang lebih baik lagi atau selfimprovement.

Rachel telah memahami siapa dirinya dan apa yang ia ingin keluarkan dari dirinya bagi orang lain. Rachel secara sadar mengetahui bahwa ia memiliki ketertarikan pada dunia beauty, berdasarkan dari pengalamannya berkecimpung dalam dunia kecantikan selama 8 tahun lamanya, hingga ia memutuskan untuk menjadi seorang freelancer $M U A$, ia sudah mengetahui bahwa dari dalam dirinya, ia memiliki keinginan untuk menggeluti dunia kecantikan dan juga memiliki kemampuan yang ingin ia bagikan kepada orang lain. Tidak hanya itu, Rachel juga suka untuk traveling yang juga merupakan salah satu hobby-nya, sehingga Rachel memiliki keinginan untuk menyatukan semua hal yang ia sukai dan menjadikannya konten yang membahas hal-hal tersebut menjadi bagian dari dirinya. Sehingga ketika ia memasuki dunia digital, ia sudah memiliki pemahaman 
yang kokoh mengenai dirinya yang adalah seorang beauty, travel and parody vlogger.

Selain harus mengetahui identitasnya, menemukan citra atau brand apa yang ingin disampaikan juga perlu dilakukan oleh sang pelaku personal branding. Berdasarkan observasi peneliti, dapat dilihat bahwa Rachel Goddard ingin menunjukkan citra dari seorang beauty, travel \& parody vlooger yang seperti apa. Dalam wawancara yang dilakukan dengan peneliti, Rachel mengakui bahwa ia selalu menanamkan kejujuran dalam aspek apapun, terutama bagi kontenkontennya.

\section{Berdasarkan pengamatan} yang dilakukan oleh peneliti terhadap konten video yang ada pada channel youtube Rachel, dapat dinilai bahwa Rachel telah mengetahui citra yang ingin ia tunjukkan kepada khalayak. Rachel memahami sifat yang ada dalam dirinya, sehingga sifat itulah yang berusaha ia tunjukkan dalam setiap videonya. Dalam wawancara yang dilakukan oleh peneliti dapat diamati bahwa Rachel merupakan seorang individu yang jujur dan apa adanya, dalam berkomunikasi ataupun menjalani kehidupan seharihari. Kejujuran yang ia tunjukkan tidak hanya mengenai pembahasan dalam videonya namun juga mencangkup kejujuran terhadap dirinya sendiri atau pribadinya. Sehingga Rachel tidak malu menunjukkan dirinya yang apa adanya sebagai bukti perilaku jujur yang ia bagikan kepada para penontonnya.

Selain mengetahui identitas yang ia miliki juga brand yang ingin disampaikan, hal yang sangat penting sebelum melakukan personal branding adalah memahami tujuan yang dimiliki oleh individu tersebut. Menurut William Arruda, saat seseorang telah memiliki tujuan dalam hidupnya, tentu akan dapat membantu tindakan yang akan ia lakukan (Arruda \& Dixson, 2007: 38). Arruda (2007: 39) menjelaskan pentingnya tujuan dalam proses personal branding, menempatkan tujuan pada level tertinggi dalam benak dan pikiran, seseorang dapat mengalokasikan waktu dan tenaga atas tindakan yang dilakukan untuk mencapai hasil dari tujuan tersebut (Arruda \& Dixson, 2007: 39). 
Bagi Rachel Goddard, tujuan yang ia miliki dalam dunia vlogging adalah untuk mengencourage perempuan-perempuan Indonesia untuk bisa lebih menghargai dirinya sendiri, agar mereka lebih mencintai diri sendiri, dan bangga dengan apa yang dimiliki oleh tubuhnya. Sehingga dengan percaya diri, mereka bisa menjalani hidupnya dengan apa yang dia miliki.

Dengan memiliki tujuan yang jelas, maka tindakan yang hendak dilakukan pun akan lebih terarah, namun dalam melaksanakan tindakan tersebut, butuh juga didukung dengan keterampilan yang menunjang tindakan tersebut. Berdasarkan wawancara peneliti dapat diamati bahwa Rachel memiliki keterampilan dalam bermake-up yang dengan jelas dapat terlihat dari hasil hasil karya tangannya yang rupawan, dan juga ia terampil dalam mempersuasi yang mempengaruhi orang-orang dalam melakukan keputusan saat berbelanja. Dalam melakukan kegiatannya sebagai beauty travel \& parody vlogger Rachel memang memiliki ketrampilan, namun tidak seimbang dengan konten yang ia miliki yang mencangkup 3 aspek yaitu beauty, travel dan parody. Ketrampilannya di bidang kecantikan atau beauty dapat dibilang sangat baik dan Rachel juga sudah memahami bahkan menguasai banyak sekali teknik terkait dengan beauty.

Rachel Goddard memang membahas konten yang berkaitan dengan beauty, travel dan parody, namun pada kenyataannya perbandingan konten yang dibuatnya tidaklah seimbang. Menurut data catatan pribadi peneliti, jumlah konten beauty yang diunggahnya sangat berbeda jauh dengan jumlah konten yang lainnya. Sehingga membuat para pentonnya tidak mendapatkan konsep branding beauty, travel and parody vlogger secara merata. Walaupun Rachel memang membahas konten-konten tersebut, namun intensitas dalam membahas konten tersebut juga mempengaruhi pengertian para penontonnya mengenai branding tersebut.

Selain itu, hal yang juga penting bagi proses personal branding adalah target audiens. Dalam bukunya, William Arruda menjelaskan bahwa bagian penting 
dalam komunitas brand yang membantu untuk mencapai tujuan dari karier utama adalah target audiens. (Arruda \& Dixson, 2007:63). Arruda menjelaskan pentingnya target audiens adalah bagian dari komunitas merek Anda yang paling penting bagi kemampuan Anda untuk mencapai tujuan karier utama Anda. Dan Anda harus terus berhubungan dengan mereka. Anda harus memulai percakapan dengan mereka dan membuat percakapan terus berjalan. Melalui pertukaran yang sedang berlangsung ini, Anda memupuk hubungan yang kuat penting untuk mencapai tujuan Anda."

Sehingga sesuai dengan tahap extract yang dikemukakan William Arruda, Rachel Goddard telah memahami hal-hal yang ada pada dirinya yaitu tujuan, hasrat, juga kemampuan. Sehingga dalam proses personal branding yang dilakukan seharusnya akan lebih mudah dilakukan dan dapat diminimalisir adanya kesenjangan yang besar antara apa yang diharapkan masyarakat dan apa yang ingin dikeluarkan dari diri Rachel Goddard.
Tahap Express (mengekspresikan) dalam Proses Personal Branding Rachel Goddard Sebagai Beauty Travel Parody Vlogger

Setelah mengetahui dan memahami siapa dirinya, saatnya bagi seseorang yang akan melakukan personal branding mengkomunikasikan hal-hal yang ia yakini dan miliki tersebut. Arruda menyatakan bahwa diperlukan identitas online karena hal tersebut dapat mempengaruhi brand yang dibangun. Secara lebih rinci Arruda (2007: 116) menjelaskan pada era millennium saat ini, semua hal serba digital. Dengan mudahnya setiap orang dapat mencari tahu orang lain hanya dengan mengetik namanya di mesin pencari otomatis di dunia maya. Web saat ini telah menggantikan sumber pencarian tradisional dan sering kali menjadi tempat pertama untuk mencari informasi mengenai orang lain. Bagaimana seseorang ditampilkan pada internet dapat mempengaruhi brand yang dibentuk hingga karir yang tengah dibangun. Oleh karena itu penting halnya memiliki sebuah identitas online yang unik, khas, dan 
berbeda dari individu lainnya (Arruda \& Dixson, 2007: 116).

Berdasarkan pengamatan yang dilakukan peneliti, Rachel Goddard memiliki ciri khas atau keunikan tersendiri dalam video blognya. Terlihat pada caranya menyampaikan pesan dengan mimik yang tidak biasa, itu menjadi daya tarik tersendiri bagi masyarakat terhadap Rachel. Sifatnya yang jujur dan apa adanya membuat Rachel tidak sungkan untuk menunjukkan sisi kekonyolan dirinya di layar kaca dengan menunjukkan mimik dan juga gesture yang unik dan beda dari biasanya ketika mengingat bahwa konten yang disuguhkan berupa beauty, travel \& parody. Dalam kontennya gerakan-gerakan tersebut akan muncul pada beberapa moment, saat Rachel membuka video, meminta likes dan subscribe dan saat-saat lainnya yang menjadi aksi spontan dari Rachel.

\footnotetext{
Rachel sangat sering menunjukkan mimik-mimik yang aneh dan tidak biasa, terutama saat membahas tentang konten kecantikan atau beauty. Namun, Rachel tidak terlihat malu saat melakukannya, namun memang itulah sesuatu yang
}

mencitrakan dirinya sebagai Rachel, yang jujur dan apa adanya sebagai seorang beauty travel \& parody vlooger.

Setelah membentuk dan membuat identitas online, selanjutnya menurut Arruda (2007: 128) yang harus dilakukan dalam proses personal branding adalah dengan mengembangkan rencana untuk memperluas identitas online tersebut. Untuk membuat identitas online yang tepat bagi brand, terdapat beberapa cara. Salah satu caranya adalah dengan membuat konten menarik dari media yang dipilih. Saat seseorang menggunakan alat atau media secara bijak, ia mengolah suatu identitas online yang membuat dirinya muncul dalam hasil pencarian sesuai yang diinginkan (Arruda \& Dixson, 2007: 128).

Bagi seorang vlogger, konten merupakan hal yang penting. Bagaimana caranya mengekpresikan dirinya melalui video blognya salah satunya adalah dengan pembutan konten yang berkualitas. Konten yang berkualitas ini dapat dicapai dengan adanya keterampilan yang sebelumnya telah ditemukan di tahap extract. Dan juga sebagai penyalur 
kreatifitas yang dimilikinya sebagai seorang content creator.

Konten yang dimiliki Rachel sangat menarik, pengemasan yang berbeda juga dilakukan, namun tidak pada semua video. Dalam artian, banyak dari videonya yang juga sudah dilakukan oleh vlogger lain dengan cara dan pengemasan yang sama. Namun, dalam penggabungan kontennya yaitu kecantikan, jalanjalan dan parodi, tidak ada yang memiliki selain Rachel. Sehingga kelucuan dan kejenakaan dari mimik dan juga gerakan Rachel adalah keunikan yang menjadikan kontennya berbeda. Juga inovasi yang dilakukan dalam segmen-segmen barunya, seperti review jujur yang dimana ia secara gamblang menyuarakan apa yang menjadi opininya terhadap beberapa benda kecantikan yang disampaikan secara jujur sesuai dengan apa yang ia rasa. Inovasi yang dilakukan Rachel membuatnya semakin digemari penonton Youtube dan kepercayaan mereka pun meningkat terhadapnya. Namun, dalam keunikannya menyampaikan pesan yang digabungkan dengan parodi, banyak juga yang menganggap hal tersebut tidak lucu atau bahkan norak, merujuk kepada hasil pra riset yang dilakukan peneliti, bahwa dari 20 responden yang merupakan subscibers Rachel, 30\% beranggapan bahwa Rachel tidak lucu bahkan $15 \%$ beranggapan bahwa Rachel menunjukkan konten yang norak. Hal tersebut membenarkan pendapat Leonita bahwa kadang konten parodi yang dimiliki Rachel kadang dilebih-lebihkan sehingga sudah tidak lagi menjadi konten yang menarik dan menghibur melainkan sebaliknya.

Hal lainnya yang penting untuk diperhatikan dalam mengkomunikasikan personal brand terhadap khalayak adalah cara berbicara. William Arruda (2007: 105) mengatakan bahwa untuk mengembangkan komunikasi yang akan dilakukan, salah satu yang terpenting dilihat adalah cara berbicara. Berbicara di depan umum adalah cara terbaik bagi orang lain untuk menerima brand seseorang. Dengan mendengarkan dan melihat, penonton dapat dengan segera menilai seseorang. Seseorang dapat mengekspresikan personal brandnya melalui pemilihan kata, cara bicara, 
ekspresi wajah (Arruda \& Dixson, 2007: 105).

Rachel sangat berhati-hati dalam pemilihan kata-kata. Sebisa mungkin, kalimat yang diucapkan tidak mengandung kata-kata negatif yang sensitif bagi penonton di bawah umur. Walaupun seperti yang sudah dibahas sebelumnya bahwa target audiens yang ia tetapkan merupakan usia 18 hingga 35 tahun, namun kenyataannya tidak sedikit juga yang berusia dibawah dari umur tersebut, hal ini diungkapkan oleh Rachel pada saat diwawancarai.

Oleh karena youtube merupakan media yang bebas, yang dapat dinikmati oleh segala kalangan, maka ia berusaha untuk tetap menyajikan hal-hal yang positif saja. Namun karena suasana dari setiap video Rachel bertata santai, sehingga pemilihan kata yang dipakai merupakan kata-kata sederhana, ringan, ramah dan akrab. Karena Rachel ingin menganggap bahwa penontonnya adalah sahabatnya sendiri, yang bisa diajak bicara mengenai berbagai macam hal yang menarik namun santai.

Salah satu hal yang juga harus diperhatikan dalam membangun identitas online adalah kreativitas. William Arruda (2007:141) mengatakan bahwa pimpin dengan kekuatan Anda. Gunakan kreativitas Anda, pemahaman tentang bidang subjek Anda, keterampilan komunikasi, dan kekuatan lain untuk menunjukkan kecakapan profesional Anda secara online.

Apabila dipadukan dengan tahap express dari konsep yang dimiliki William Arruda, yang dilakukan Rachel Goddard dapat dikatakan berkaitan. Rachel Goddard telah memastikan identitas onlinenya sebagai cara untuk mengekspresikan personal brandnya. Selain itu Rachel juga memiliki karakteristik juga kriteria bagi dirinya sendiri dalam mengkomunikasikan personal brandnya melalui video blog.

Tahap Exude (mempertunjukkan) dalam Proses Personal Branding Rachel Goddard Sebagai Beauty Travel Parody Vlogger

Setelah kedua tahap telah dicapai, tahap terakhir adalah tahap mempertunjukkan, dengan artian bagaimana cara mempertunjukkan konsistensi agar personal brand yang telah dibangun terus melekat pada 
target audiens. Menurut William Arruda, salah satu caranya adalah dengan mengatur lingkungan brand. William Arruda menjelaskan mengenai lingkungan brand yang dimaksud mengatur lingkungan brand dengan maksud mengatur lingkungan di sekitar adalah cara yang tepat untuk mempertahankan personal brand. Lingkungan brand dapat diartikan seperti pakaian yang dikenakan, peralatan bekerja, hingga pihak-pihak yang dapat mendukung keberlangsungan karir seseorang (Arruda \& Dixson, 2007: 146-147).

Penampilan menurut William Arruda adalah hal yang penting dalam mempertunjuukan personal brand seseorang. Saat seseorang melihat atau bertemu orang lain pertama kali maka ia dapat membuat impresi instan saat itu juga. Oleh karena itu William Arruda (2007: 149) mengatakan pentingnya penampilan membuat impresi terbaik saat pertemuan pertama adalah hal yang krusial. Seseorang sebaiknya menyelaraskan penampilannya dengan apa yang ia ingin tampilkan untuk memperkuat pesan brand dalam suatu pertemuan awal. Penampilan seseorang harus pantas atau sesuai dengan target audiensnya. Pikirkan bahwa pakaian yang dikenakan adalah biaya pemasaran yang harus ditanggung. Pakaian dapat melakukan hal yang sama bagi personal brand seseorang (Arruda, 2007: 149-150).

Rachel tidak memiliki style tertentu yang menjadi cirikhasnya, karena stylenya cenderung berubahubah terutama dalam hal berpakaian dan gaya rambut. Rachel termasuk orang yang mengikuti trend dalam berpaiakan sehingga ia tidak memiliki gaya tertentu yang spesifik yang menjelaskan mengenai dirinya, namun gaya yang selalu ditunjukkannya dalam videonya selalu menyesuaikan dengan tempat dan situasi, namun biasanya cenderung dengan gaya casual. Gaya penampilan yang casual mendukung citra yang ingin disampaikan sebagai beauty travel \& parody vlogger yang jujur dan apa adanya.

Selain penampilan, dalam mempertunjukkan konsistensi personal brand, alat-alat yang digunakan dalam bekerja juga dapat digunakan untuk memperkuat brand seseorang. Arruda (2007: 151-153) menyatakan pentingnya alat-alat 
pekerjaan dalam membangun personal brand seseorang dapat ditebak kepribadiannya dengan melihat ruang kerjanya. Kantor dan peralatan kerja dapat menetukan brand seseorang. Tidak hanya alatalat bekerja kantoran yang dapat membentuk apa yang orang pikirkan terhadap seseorang. Setiap alat pekerjaan yang seseorang gunakan dapat mengirimkan pesan brand, seperti peralatan komunikasi dan teknologi yang digunakan saat itu. Contohnya bagi orang yang menggunakan peralatan canggih, hal itu menunjukkan bahwa ia familiar dengan teknologi terbaru (Arruda \& Dixson, 2007: 151-153).

Dalam melakukan pekerjaannya sebagai vlogger, Rachel memakai beberapa jenis peralatan yang mendukungnya dalam membuat video blognya. Peralatan-peralatan tersebut adalah kamera Sony A7 Mark II dan kamera Canon G7X. Peralatan ini dimiliki oleh Rachel secara bertahap dan dipakai sesuai dengan keperluannya masing-masing dibedakan dari kesederhanaan dan kemudahan handling saat pemakaian untuk kegiatan outdoor yang melakukan banyak pergerakan dan indoor yang cenderung diam di tempat.

Menurut Arruda (2007: 173): kesuksesan tidak terjadi dan lahir dengan sendiri. Penting untuk menjalin hubungan dengan pihak lain dalam melakukan personal branding. Relasi atau dapat diartikan dengan orang-orang yang berhubungan dengan individu yang melakukan personal branding adalah elemen penting dalam lingkungan brand seseorang. Saat orang lain menghargai, memahami brand yang dibentuk oleh seseorang, maka orang itu secara langsung maupun tidak langsung dapat mempengaruhi kesuksesan dirinya (Arruda \& Dixson, 2007: 173).

Dalam melakukan personal branding, penting halnya untuk menentukan pihak-pihak yang terkait di dalamnya. Tidak ada salahnya untuk menjalin relasi dengan pihak lain yang dapat mendukung personal brand seseorang. Rachel pun melakukan hal yang sama yaitu bekerja sama dengan pihak lain yang dapat memberikan pengaruh bagi dirinya sebagai beauty travel \& parody vlogger. 
Berdasarkan pengamatan dan wawancara peneliti, Rachel Goddard telah melakukan kerjasama dengan beberapa pihak seperti produk teknologi, perusahaan e-commerce, makanan, pakaian, situs berbelanja, alat kecantikan, produk kecantikan dan sebagainya. Rachel pernah bekerja sama dengan Mizzu Cosmetics dalam membuat sebuah lipstick, mejadi pembicara di berbagai beauty event yang bekerja sama dengan Nivea, BrunBrun, Clozette Indonesia membicarakan tentang parenting, dan banyak lainnya.

Tidak hanya itu, Rachel juga sering melakukan kolaborasi dengan youtubers tanah air lainnya seperti Ria Ricis, Laurentius Rando, Minyo, Cameo Project dan yang baru-baru ini ada Najwa Shihab. Kolaborasi merupakan hal yang juga menguntungkan bagi Rachel dan juga untuk partner kolaborasinya, karena mereka dapat saling mempromosikan kanal youtube masing-masing.

Berbagai pengalaman yang dilewati oleh Rachel, membuat dirinya semakin dikenal banyak orang dan memantapkan dirinya di dunia vlogger. Hal ini dibuktikan saat ia masuk dalam nominasi dan bahkan memenangkan penghargaan yang diberikan BeautyFest Asia 2 tahun berturut-turut. Pada 2017, Rachel memenangkan kategori Beauty Lifetime Achievement dan pada tahun 2018 Rachel memenangkan kategori Beauty Creator of The Year. Rachel dianggap telah mencapai puncak kejayaannya, tetapi hal ini tidak merubah sifatnya yang rendah hati.

Menurut William Aruuda, semakin seseorang memberi kepada orang lain semakin ia mendapatkan kembali bahkan lebih. Salah satu strategi yang efektif untuk membangun hubungan dan jaringan adalah melalui pemberian ke masyarakat (Arruda \& Dixson, 2007: 181). Rachel sadar bahwa dirinya sekarang ini tidak akan bisa sama tanpa dukungan yang didapat dari para penontonnya. Maka ia seringkali mengadakan gathering santai yang sering ia gelar ketika ia sedang ada di luar kota membuat janjian dengan para Rachelova yang berdomisili di daerah tersebut. Rachel juga kerap kali mengadakan giveaway untuk mengapresiasi para viewers dan subscribers kanal Youtubenya.

Rachel sudah melakukan kebanyakan dari interaksi yang 
seharusnya dilakukan oleh seorang youtuber untuk mendapatkan engagement dan feedback dari viewers dan subscribersnya. Hal yang terpenting adalah feedback atau masukan yang membangun para youtubers tersebut. Beberapa media sosial juga sekarang sudah memiliki fitur yang memudahkan para viewers untuk memberikan feedback dengan cepat. Feedback ini kemudian diolah untuk menjadi konten yang menarik para viewers dengan pengemasan yang memiliki ciri khas dari setiap youtuber yang membedakan karya mereka satu dengan yang lainnya dan juga bahkan bisa mengajak para viewers dan subscribers untuk berkolaborasi.

Menurut Arruda (2007:157): sebagai bagian penting dari langkah ketiga yaitu exude, harus ada sistem yang secara konsisten mengirimkan pesan yang sama mengenai nilai merek yang dimiliki seseorang. Nilai dari merek tersebut dapat berbentuk tipografi, karya seni, logo, tagline dan standar tata letak on-brand untuk semua alat pemasaran. Atau secara garis besar dapat dibilang bahwa nilai dari brand tersebut diuji kekonsistenannya dari lebih dari satu elemen yang menjadi kunci keunikannya. Sebagai bagian penting dari Langkah 3: Exude - Kelola Lingkungan Merek Anda, Anda perlu mengembangkan dan menggunakan sistem identitas merek yang disesuaikan. Pikirkan sistem identitas merek Anda sebagai kosakata visual yang mempromosikan merek Anda. Anda membangun sistem dengan memilih tipografi, karya seni, logo, tagline, dan standar tata letak onbrand untuk semua alat pemasaran karier cetak Anda dan online. Untuk secara konsisten mengirim pesan yang sama tentang janji nilai unik Anda, Anda menerapkan sistem identitas merek Anda di semua alat komunikasi Anda.

Berdasarkan dari observasi yang dilakukan peneliti, konsistensi yang dilakukan Rachel dalam vlognya masih kurang dan kadang terlupakan. Mendukung Leonita, dapat terbilang bahwa penataan pada playlist yang dimiliki Rachel masih kurang teratur, bahwa Rachel kurang memperhatikan pengaturan dan pengelompokkan dari video-video yang pernah diunggahnya. Pada segi judul juga bahwa Rachel tidak memiliki ciri khas khusus yang dapat 
dilihat pada judulnya, namun dapat dicirikan berdasarkan thumbnail bahwa ia menggunakan warna tertentu untuk mencirikan karyanya, namun dapat dilihat juga bahwa warna-warna tersebut tidak selalu digunakan pada setiap video. Juga jika dilihat dalam segi konten, memang Rachel dalam beberapa videonya juga tidak menggunakan ciri khas 'jempol' yang sering ia lakukan untuk meminta like. Hal-hal ini membuat kekonsistenan Rachel ternilai kurang.

Terdapat relevansi antara tahap exude dalam konsep proses personal branding yang disebutkan William Arruda dengan apa yang dilakukan oleh Rachel Goddard. Dalam mempertahankan personal brandnya, Rachel Goddard memperhatikan lingkungannya. Dalam artian lingkungan dirinya sendiri seperti penampilan dan peralatan, juga lingkungan eksternal yaitu pihak lain yang dapat berpengaruh bagi personal brandnya. Selain itu ia juga tidak lupa bahwa apa yang ia beri adalah apa yang akan ia dapat. Dengan memberikan perhatian dan apresiasi terhadap audiens, ia yakin akan mendapatkan hal yang sama. Namun dalam beberapa hal, rachel tidak mempertahankan konsistensinya terutama dalam menggunakan identitas onlinenya.

\section{KESIMPULAN}

Personal branding menjadi sebuah tools yang digunakan berbagi pihak untuk mencapai tujuan masingmasing dengan menampilkan dirinya sebagaimana ia ingin dinilai orang lain. Hal ini dirasa dapat menjadi cara untuk memberi atau mendapatkan sesuatu yang diinginkan dengan menunjukkan siapa dirinya dan apa yang diwakilinya. Personal branding membuktikan bahwa kegiatan public relations pada era modern ini tidak lagi hanya terpaku pada kegiatan organisasi dan perusahaan, namun manusia sebagai seorang individu juga dapat menjadi PR bagi dirinya sendiri.

Personal branding yang dilakukan oleh Rachel Goddard sebagai seorang beauty, travel and parody vlogger di Indonesia bertujuan agar perempuanperempuan Indonesia bisa lebih menghargai dirinya sendiri, bangga terhadap apa yang dimiliki tubuhnya, dengan keberagaman warna kulit, bentuk tubuh dan tinggi badan, tapi 
bisa tetap percaya diri apa adanya.

Oleh karena itu Rachel berusaha menunjukkan dirinya yang apa adanya dalam karirnya sebagai beauty, travel \& parody vlogger dengan memberikan konten-konten yang kreatif dan mengemas setiap kontennya dengan menarik serta menunjukkan dirinya yang apa adanya dalam setiap kontennya. Penelitian ini kemudian akan membahas proses personal branding Rachel Goddard sebagai beauty, travel \& parody vlogger menggunakan konsep tiga tahap proses personal branding William Arruda yang terdiri dari extract (mengeluarkan), express (mengekspresikan), exude (mempertunjukkan).

\section{DAFTAR PUSTAKA}

Arruda, William dan Dixson, Kirsten.

2007. Career Distinction:

Stand Out by Building Your

Brand. New Jersey: John

Wiley \& Sons, Inc.

Bungin, Burhan. 2007. Penelitian Kualitatif: Komunikasi, Ekonomi, Kebijakan Publik, dan Ilmu Sosial Lainnya. Jakarta: Kencana.
Burgess, Jean dan Green, Joshua. 2009. Youtube: Digital Media and Society Series. Cambridge: Polity Press.

Chen, Chih-Ping. 2013. Exploring Personal Branding on Youtube. Journal of Internet Commerce, hal 334.

Creswell, John W. 1998. Qualitative Inquiry and Research Design: Choosing Among Five Traditions. California: SAGE Publications, Inc.

Finamore, Alessandro dan Mellia, Marco. 2011. Youtube Everywhere: Impact of Device and Infrastucture Synergies on User Experience. ECE Technical Reports, hall.

Gao, Wen, Yonghong Tian, dan Tiejun Huang. 2010. Vlogging: A Survey of Videoblogging Technology on the Web. ACM Computing Surveys, Vol. 42, No. 4, Article 15, hal 5.

Gunawan, Imam. 2015. Metode Penelitian Kualitatif Teori dan Praktik. Jakarta: PT. Bumi Aksara.

Hasanah, Hasyim. 2016. TeknikTeknik Observasi (Sebuah 
Alternatif

Metode

Pengumpulan Data Kualitatif

Ilmu-Ilmu Sosial). Jurnal at-

Taqaddum, Volume 8, Nomor

1 , hal 36 .

Jeffkins, Frank. 2003. Public

Relations: Contemporary

Issues and Techniques.

Butterworth Heinemann. Ebook.

Kaminsky, Michael Sean. 2010.

Naked Lens: Video Blogging

and Video Journaling to

Reclaim the You in the

Youtube. New York: Organic

Media Incorporated.

Luttrell, Regina. 1975. Social Media:

How to Engage, Share and

Connect. London: Rowman \&

Littlefield.

Mobray, Kaplan. 2009. The 10Ks of

Personal Branding: Create a

Better You (paperback).

United States of America:

iUniverse.

Moleong, Lexy J. 2014. Metodologi

Penelitian

Kualitatif.

Bandung: Remaja

Rosdakarya.

Montoya, Peter. 2009. The Brand

Called You. New York:

McGraw-Hill.
Mulyana, Deddy. 2003. Metodologi

Penelitian

Kualitatif

Paradigma Baru Ilmu

Komunikasi dan Ilmu Sosial

Lainnya. Bandung: Remaja

Rosdakarya.

Nazir, Moh. 2009. Metode Penelitian.

Jakarta: Ghalia Indonesia.

Parengkuan, Erwin dan Becky

Tumewu. 2014. Personal

Brand-Inc. Jakarta: PT.

Gramedia Pustaka Utama.

Shirky, Clay. 2008. Here Comes

Everybody: The Power of

Organizing without

Organization. London:

Penguin Group.

Soekmadinata, nana Syaodih. 2006.

Metode Penelitian

Pendidikan. Bandung:

Remaja Rosdakarya

Stefanoe, Michael A. dan Lackaff,

Derek. 2009. Reality

Television as a Model for

Online Behaviour: Blogging,

Photo and Video Sharing.

Journal of Computer-

Mediated Communication.

Sugiyono. 2016. Metode Penelitian

Kuantitatif, Kualitatif, dan

$R \& D$. Bandung: Alfabeta. 
Surakhmad, Winarno, 1982.

Pengantar-Penelitian Ilmiah,

Dasar, Metode, Teknik.

Bandung: Tarsito.

Van Dijck, Jose. 2013 The Culture of

Connectivity: A Critical

History of Social Media. New

York: Oxford University

Press.

Wasesa, Silih Agung. 2011. Political

Branding \& Public Relations.

Jakarta: PT Gramedia Pustaka

Utama. 